\title{
PENGARUH STRUKTUR KEPEMILIKAN INSTITUSIONAL, UKURAN PERUSAHAAN DAN DIVIDEN TERHADAP MANAJEMEN LABA PADA PERUSAHAAN MANUFAKTUR YANG TERDAFTAR DI BURSA EFEK INDONESIA PERIODE 2010-2014
}

\author{
Krisnando \\ Sekolah Tinggi Ilmu Ekonomi Indonesia Rawamangun \\ J1. Kayu jati Raya no. 11A Rawamangun Jakarta Timur \\ krisnando@gmail.com
}

\begin{abstract}
This study aims to determine the effect of ownership structure, company size and dividend to earnings management in companies listed on the Indonesia Stock Exchange, partially and simultaneously. The population in this research is manufacturing companies listed in Indonesia Stock Exchange from 2010 to 2014. List of companies listed at this time amounted to 141 companies. Based on the sampling criteria obtained a total of 18 sample companies listed in Indonesia Stock Exchange 2010-2014. The data analysis method used is Testing Assumptions Classical (Normality Test, Multicollinearity Test, Heteroskedastisity Test and autocorrelation test), Multiple Linear Regression Analysis, Hypothesis Testing (Statistic t test and F test), as well as the Test Coefficient of Determination.From the results of the study concluded that 1) The ownership structure no significant effect on earnings management in companies listed on the Indonesia Stock Exchange, so ha1 not proven, 2) The size of the company a significant effect on earnings management in companies listed on the Indonesia Stock Exchange, so that Ha2 proven, 3) dividends significant effect on earnings management in companies listed on the Indonesia Stock Exchange, so HA3 proven, 4) the ownership structure, company size and dividend significantly influence earnings management in companies listed on the Indonesia Stock Exchange, so that ha4 proven.
\end{abstract}

Keyword: Ownership Structure, Company Size, Dividend, and Earnings Management 


\section{PENDAHULUAN}

Dalam teori keagenan menekankan bahwa angka-angka laporan akuntansi memiliki peranan dalam menekankan konflik antara pemilik perusahaan dan pengelola atau manajer. Pihak-pihak yang terkait dalam hal ini disebut agen yaitu pihak yang menjalankan kepentingan dan pihak principal yaitu pihak yang mempunyai kepentingan dalam perusahaan, pihak yang disebut sebagai agen adalah para manajer dan pihak yang disebut prinsipal adalah pemilik perusahaan (Anthony et al, 1995). Munculnya konflik kepentingan antara prinsipal dan agen karena adanya ketidakseimbangan informasi mengenai perusahaan, kondisi yang terjadi principal tidak memiliki informasi yang cukup tentang kinerja agen. Sementara itu, Agen mempunyai lebih banyak informasi mengenai perusahaan secara keseluruhan baik dari sisi internal maupun eksternal. Hal inilah yang mengakibatkan adanya ketidakseimbangan informasi yang dimiliki oleh prinsipal dan agen. Atas kondisi ketidakseimbangan informasi ini disebut dengan asimetri informasi. Adanya asumsi bahwa individuindividu bertindak dalam hal untuk memaksimalkan kepentingan dirinya sendiri, mengakibatkan agen memanfaatkan kondisi asimetri informasi yang dimilikinya untuk menyembunyikan beberapa informasi yang tidak diketahui oleh prinsipal. Asimetri informasi yang terjadi antara prinsipal dan agen mendorong agen untuk menyajikan informasi yang tidak sebenarnya kepada prinsipal,terutama jika informasi tersebut berkaitan dengan pengukuran kinerja agen yang tercermin dalam laporan keuangan (Anthony et al, 1995). Prinsipal dan agen merupakan pihak yang berperan dalam pengambilan keputusan menyangkut kinerja perusahaan di masa yang akan datang. Salah satu ukuran kinerja perusahaan yang sering digunakan sebagai dasar dalam pengambilan keputusan adalah laba yang dihasilkan perusahaan dari kegiatan yang dilakukannya (Subramanyam, 1996). Laba perusahaan juga menjadi fokus utama bagi stakeholder dalam mengevaluasi tentang penilaian kinerja manajemen.

Laba perusahaan secara luas dapat digunakan oleh stakeholder untuk menentukan kompensasi bagi manajemen, menilai prospek perusahaan di masa depan melalui pengalokasiansumberdaya, dan dalam penilaian perusahaan.

Peranan laba bagi salah satu indikator penilaian kinerja perusahaan terutama terkait dengan kompensasi yang diterima oleh manajer dapat menjadi pendorong munculnya motif tindakan manajemen laba (earnings management). Hal ini menunjukkan bahwa manajemen laba berhubungan dengan tingkat perolehan laba. Besar kecilnya laba yang diperoleh perusahaan akan mempengaruhi besar kecilnya bonus atau kompensasi yang diterima oleh manajer. Kondisi tersebut mengakibatkan manajer sering berusaha memperlihatkan prestasinya melalui tingkat keuntungan laba yang dicapai. Tindakan manajemenlaba yang dilakukan dapat diminimalisasi dengan memonitor manajemen. Kepemilikan institusional umumnya dapat bertindak sebagai pihak yang memonitor perusahaan dalam menjalankan kegiatan bisnisnya. Kepemilikan institusional memiliki banyak arti bagi perusahaan. Perusahaan dengan kepemilikan institusional yang besar mengindikasikan kemampuannya untuk memonitor pihak manajemen (Moh'd et al. 1998). 
Penelitian mengenai manajemen laba akan menjadi lebih menarik dilakukan bila dikaitkan dengan fenomena baru yang muncul dalam praktik dunia bisnis, seperti kompleksitas bisnis perusahaan, termasuk struktur kepemilikan institusional perusahaan terdaftar di pasar modal asing dan ukuran perusahaan. Selain itu, bila dikaitkan dengan sistem hukum pada negara asal maka akan dapat diketahui apakah variabel ini akan mempengaruhi manajemen laba yang dilakukan meskipun perusahaan tersebut yang terdaftar di pasar modal internasional seperti pasar modal Amerika New York Stock Exchange (NYSE). Negara Amerika yang memiliki pasar modal NYSE merupakan pasar modal yang dikenal mempunyai proteksi terhadap investor yang kuat (Cernat, 2004). Hal ini menjadi menarik ketika investor lokal maupun asing melakukan investasi di pasar modal tersebut. Ukuran perusahaan digunakan sebagai variabel dalam sebagian besar penelitian mengenai manajemen laba, dan merupakan faktor penting yang berhubungan dengan struktur kepemilikan (Siregar dan Utama, 2008). Ukuran perusahaan memberikan pengaruh dalam menilai manajemen laba yang dilakukan perusahaan. Penelitian Kim et al. (2003) dan Rezaei (2012) menguji hubungan antara ukuran perusahaan dengan menggunakan discretionary accrual yang merupakan proksi dari manajemen laba. Hasil penelitian menunjukkan bahwa semakin tinggi ukuran perusahaan maka perusahaan akan mengurangi tindakan manajemen laba dengan cara memilih kebijakan yang sesuai dengan standar yang ada.

Berdasarkan pemaparan di atas, peneliti tertarik untuk meneliti pengaruh struktur kepemilikan institusional, ukuran perusahaan dan dividen terhadap manajemen laba pada perusahaan manufaktur yang terdaftar di Bursa Efek Indonesia Periode 2010-2014.

\section{LANDASAN TEORI}

\subsection{Struktur Kepemilikan}

Struktur kepemilikan merupakan bentuk komitmen dari pemegang saham untuk medelegasikan pengendalian dengan tingkat tertentu kepada para manajer. Istilah Struktur kepemilikan digunakan untuk menunjukan bahwa variabelvariabel yang penting dalam struktur modal tidak hanya ditentukan oleh hutang dan ekuitas saja tetapi juga ditentukan oleh presentase kepemilikan saham oleh manajemen dan institusi.

Menurut Sugiarto (2009: 59) struktur kepemilikan adalah struktur kepemilikan saham yaitu perbandingan jumlah saham yang dimiliki oleh orang dalam (insider) dengan jumlah saham yang dimiliki oleh investor. Atau dengan kata lain struktur kepemilikan saham adalah proporsi kepemilikan institusional dan kepemilikan manajemen dalam kepemilikan saham perusahaan. Dalam menjalankan kegiatannya suatu perusahaan diwakili oleh direksi (agents) yang ditunjuk oleh pemegang saham (principals). 
Sedangkan menurut I Made Sudana (2011:11) menyatakan Struktur kepemilikan merupakan pemisahan antara pemilik perusahaan dan manajer perusahaan. Pemilik atau pemegang saham adalah pihak yang menyertakan modal kedalam perusahaan, sedangkan manajer adalah pihak yang ditunjuk pemilik dan diberi kewenangan mengambil keputusan dalam mengelola perusahaan, dengan harapan manajer bertindak sesuai dengan kepentingan pemilik.

Struktur kepemilikan terbagi kedalam beberapa jenis. Adapun jenis-jenis struktur kepemilikan dapat dibedakan menjadi tiga, yaitu kepemilikan manajerial, kepemilikan institusional, dan kepemilikan publik. Penelitian ini memfokuskan pada kepemilikan institusional.

Kepemilikan institusional merupakan kepemilikan saham oleh pihak institusi lain yaitu kepemilikan oleh perusahaan atau lembaga lain. Kepemilikan saham oleh pihak-pihak yang terbentuk institusi seperti perusahaan asuransi, bank, perusahaan investasi, dan kepemilikan institusi lain. Kepemilikan institusional merupakan satu alat yang dapat digunakan untuk mengurangi agency conflict. Kepemilikan institusional memiliki kemampuan untuk mengendalikan pihak manajemen melalui proses monitoring secara efektif.

Dengan tingkat kepemilikan institusional yang tinggi maka akan menimbulkan usaha pengawasan yang lebih besar oleh pihak investor institusional sehingga dapat menghalangi perilaku opurtunistik yang dilakukan oleh pihak manajer serta dapat meminimalisir tingkat penyelewengan-penyelewengan yang dilakukan oleh pihak manajemen yang akan menurunkan nilai perusahaan.

Menurut Nabela (2012:2) definisi kepemilikan institusional merupakan proporsi saham yang dimiliki institusi pada akhir tahun yang diukur dengan presentase. Adapun menurut Nuraina (2012:116), kepemilikan Institusional adalah presentase saham perusahaan yang dimiliki oleh institusi atau lembaga (perusahaan asuransi, dana pensiunan, atau perusahaan lain.

Jadi dengan kata lain kepemilikan institusional merupakan proporsi saham yang dimiliki pihak institusi seperti perusahaan asuransi, dana pensiunan atau perusahaan lain yang diukur dengan presentase yang dihitung pada akhir tahun.

\subsection{Ukuran Perusahaan}

Menurut Agus Sartono (2010:249), perusahaan besar yang sudah wellestablished akan lebih mudah memperoleh modal di pasar modal dibanding dengan perusahaan kecil. Karena kemudahan akses tersebut berarti perusahaan besar memiliki fleksibilitas yang lebih besar pula.

Menurut Irham Fahmi (2012:2), semakin baik kualitas laporan keuangan yang disajikan maka akan semakin menyakinkan pihak eksternal dalam melihat kinerja keuangan perusahaan tersebut, yang otomatis tentunya pihak-pihak yang 
berhubungan dengan perusahaan akan merasa puas dalam berbagai urusan dengan perusahaan.

Perusahaan selalu menginginkan perolehan laba bersih setelah pajak karena bersifat menambah modal sendiri. Dengan kata lain, laba bersih dapat diperoleh jika jumlah penjualan lebih besar daripada jumlah biaya operasi. Agar diperoleh laba bersih yang sesuai dengan jumlah yang diinginkan, maka perencanaan dan pengendalian menjadi hal yang sangat penting dilakukan oleh pihak manajemen.

Perusahaan yang berada pada pertumbuhan penjualan yang tinggi membutuhkan dukungan modal yang semakin besar, demikian juga sebaliknya, pada perusahaan yang tingkat pertumbuhan penjualannya rendah kebutuhan terhadap modal juga semakin kecil. Akan tetapi, jika dana dari sumber intern sudah tidak mencukupi, maka tidak ada pilihan lain bagi perusahaan untuk menggunakan dana yang berasal dari luar perusahaan, baik utang maupun dengan mengeluarkan saham baru.

Perusahaan yang besar cenderung memiliki sumber permodalan yang lebih banyak dan memiliki kemungkinan untuk bangkrut yang lebih kecil, sehingga lebih mampu untuk memenuhi kewajiban finansialnya. Dengan kata lain, perusahaan besar cenderung memiliki utang atau menggunakan dana eksternal dalam jumlah yang lebih besar.

Menurut Bambang Riyanto (2008;299-300), suatu perusahaan yang besar yang sahamnya tersebar sangat luas, setiap perluasan modal saham hanya akan mempunyai pengaruh yang kecil terhadap kemungkinan hilangnya atau tergesernya pengendalian dari pihak yang dominan terhadap perusahaan bersangkutan.

Dengan demikian, maka perusahaan yang besar akan lebih berani mengeluarkan saham baru dalam memenuhi kebutuhan untuk membiayai pertumbuhan yang didasarkan pada penjualan, dibandingkan dengan perusahaan yang kecil. Ukuran perusahaan diukur dengan logaritma total aset perusahaan.

Size $\quad=$ Ln Total Aset

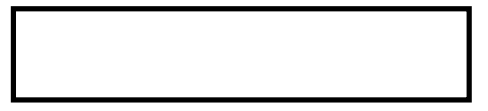

\subsection{Dividen}

Dividen adalah pembagian keuntungan yang diberikan perusahaan penerbit saham tersebut atas keuntungan yang dihasilkan perusahaan. Dividen diberikan setelah mendapat persetujuan dari pemegang saham dalam RUPS. dalam

Menurut Siegel dan Shim dalam Taofiqkurochman dan Konadi (2012:24), 
"Kamus Istilah Akuntansi menyatakan dividen adalah pembagian penghasilan yang dibayarkan kepada pemegang saham berdasarkan pada banyaknya saham yang dimiliki."

Sedangkan menurut Timothy and Joseph D. Andrew dalam Taofiqkurochman dan Konadi (2012:24):

"Dividend are cash payment that corporations make to their common stock holders. Dividend provide the return common stock holders receive from the firm for the equity capital they have supplied. Even companies that, do not currently pay dividend reinvest in the firm the earning they generate. In this way they increase the ability of the firm to pay dividends in the future."

Weston dan Copeland dalam Taofiqkurochman dan Konadi (2012:24), berpendapat bahwa dividen merupakan arus kas yang disisihkan untuk pemegang saham. Demikian juga dikatakan oleh Emery dan Finnery dalam Taofiqkurochman dan Konadi (2012:24) menyebutkan: "Dividend payments are generally made in cash."

Kebijakan dividen menyangkut masalah penggunaan dana yang menjadi hak para pemegang saham (laba biasa dibagi sebagai dividen atau ditahan untuk diinvestasikan kembali). Menurut Alan C, Shapiro, Shaldon D dan Balbirer dalam Taofiqkurochman dan Konadi (2012:25) pengertian kebijakan dividen adalah "Dividend policy is he decision of profits between payments to shareholders and reinvestment in the firm. As such it is an important component of the firm's long run financing strategy. Earnings retained in the firm can fund additional invest-ments or retire debt."

Pengertian Kebijakan Dividen menurut Gitman, Juchau, dan Flanagon dalam Taofiqkurochman dan Konadi (2012:25) adalah sebagai berikut : "Dividend policy is affected by certain legal, contractual internal constraints as well as growth prospects, owner considerations and market considerations. The three basic type of dividend policy: with a constant-payout ratio dividend policy, the firm pays a fixed percentage of earnings out to the owners each period with this policy, dividends move up and down with earning, and no dividend is paid when a loss occurs."

Riyanto dalam Kadir (2010:15) menyatakan bahwa kebijakan dividen berhubungan dengan penentuan pembagian pendapatan (earning) antara penggunaan pendapatan untuk dibayarkan kepada para pemegang saham sebagai dividen atau untuk digunakan di dalam perusahaan yang berarti pendapatan tersebut harus ditahan di dalam perusahaan.

Keputusan keuangan yang berkaitan dengan penentuan berapa besarnya laba yang tersedia bagi para pemegang saham biasa yang dibagikan kepada para pemegang saham biasa sebagai dividen dan berapa banyak jumlah yang ditahan sering disebut dengan keputusan dividen. Keputusan dividen dalam perusahaan akan menghasilkan kebijakan dividen. Kebijakan keuangan ini 
merupakan keputusan yang penting, karena dapat berpengaruh terhadap nilai perusahaan. dengan demikian kebijakan dividen yang tepat dapat berimplikasi terhadap kekayaan para pemegang saham perusahaan.

Munawir dalam Kadir (2010:15) menjelaskan indikator yang digunakan untuk mengukur kebijakan dividen adalah rasio pembayaran dividen (dividen payout ratio/DPR). Dividen Payout ratio (DPR) mengukur bagian laba yang diperoleh untuk perlembar saham umum yang akan dibayarkan dalam bentuk dividen.

Kebijakan dividen dalam penelitian ini diproksikan dengan dividen payout ratio. Dividend Payout Ratio merupakan dividen perlembar saham dibagi laba per lembar saham. Rasio ini menunjukkan persentase laba perusahaan yang dibayarkan kepada pemegang saham dalam bentuk kas.

Dividend Payout Ratio diukur dengan membandingkan antara dividend per share dan earning per share.

\begin{tabular}{|l|}
\hline $\mathrm{PR}=$ \\
$\frac{\text { Dividen per Share }}{\text { Earning per Share Dividen }}$
\end{tabular}

Payout Ratio banyak digunakan dalam penilaian sebagai cara pengestimasian dividen untuk periode yang akan datang, sedangkan kebanyakan analisis mengestimasikan pertumbuhan dengan menggunakan laba ditahan dengan lebih baik daripada dividen. Sehingga kebijakan dividen dalam penelitian ini merupakan rasio hasil perbandingan dividen dan laba yang tersedia bagi para pemegang saham biasa.

\subsection{Manajemen laba}

Menurut Scott dalam Indraswono (2015:149), manajemen laba merupakan cara penyajian laba keuangan yang disesuaikan dengan tujuan tertentu yang diinginkan manajer, melalui pemilihan satu set kebijakan akuntansi atau melalui pengelolaan akrual. Pemilihan ini dapat dilakukan misalnya dengan tujuan memaksimalkan kepentingan mereka sendiri dan atau meningkatkan nilai pasar perusahaan mereka.

Salah satu bentuk pemanfaatan fleksibilitas dan peluang dalam menentukan standar akuntansi akan tercermin dari kebijakan akrual. Fleksibilitas tersebut memungkinkan manajemen perusahaan melakukan pengelolaan laba yang sah tanpa melanggar ketentuan standar, artinya manajemen laba merupakan tindakan 
legal yang memanfaatkan berbagai fleksibilitas dan peluang yang ada dalam standar akuntansi.

Menurut Suhendah dalam Syahrial (2013:3), manajemen laba (Earning management) adalah suatu konsep yang dilakukan perusahaan dalam mengelola laporan keuangan supaya laporan keuangan tampak terlihat memiliki kualitas (quality of financial reporting).

Manajemem laba menurut Schipper dalam Machmuddah (2013:3) adalah proses pelaporan keuangan eksternal dengan sengaja dan memiliki maksud tertentu, untuk memperoleh beberapa keuntungan pribadi.

Adapun menurut Fischer dan Rosenzweig dalam Machmuddah (2013:3) manajemen laba adalah tindakan seorang manajer untuk menaikkan (menurunkan) laba perusahaan yang dikelolanya pada periode berjalan, tanpa menyebabkan kenaikan (penurunan) keuntungan ekonomi perusahaan dalam jangka panjang.

Berdasarkan pengertian manajemen laba di atas, maka dapat disimpulkan bahwa manajemen laba merupakan campur tangan manajemen dalam proses pelaporan keuangan dengan tujuan untuk menguntungkan dirinya sendiri (manajer) yaitu dengan menaikkan laba, menurunkan laba, perataan laba maupun taking a bath (menurunkan laba pada nilai yang tinggi pada saat perusahaan mengalami kerugian dengan cara meningkatkan aktiva).

Adanya praktik manajemen laba dalam pengelolaan perusahaan oleh manajer dapat dijelaskan berdasarkan agency theory. Pihak-pihak yang terlibat dalam perusahaan (manajer, pemilik, kreditor, karyawan) akan berperilaku oportunis karena pada dasarnya mempunyai kepentingan yang berbeda.

Scott dalam Jaryanto (2008:25) mendefinisikan manajemen laba adalah "Given that managers can choose accounting policies from a set (for example,GAAP), it is natural to expect that they will choose policies so as to maximize their own utility and/or the market value of the firm", yang mengandung arti bahwa manajemen laba merupakan pemilihan kebijakan akuntansi oleh manajer dari standar akuntansi yang ada dan secara alamiah dapat memaksimumkan utilitas mereka dan atau nilai pasar perusahaan.

Scott dalam Jaryanto (2008:25) membagi cara pemahaman atas manajemen laba menjadi dua, yaitu;

1. Perspektif perilaku oportunis manajer karena manajer selalu berusaha memaksimumkan utilitasnya dalam menghadapi kontrak kompensasi, kontrak utang, dan political costs (opportunistic earnings management) dan

2. perspektif efficient contracting (efficient earnings management) karena manajemen laba memberikan manajer suatu fleksibilitas untuk melindungi diri mereka dan perusahaan dalam mengantisipasi kejadian-kejadian yang tak terduga untuk keuntungan pihak-pihak yang terlibat dalam kontrak. 
Dengan demikian, manajer dapat mempengaruhi nilai pasar saham perusahaannya melalui manajemen laba.

Scott dalam Aryanti (2009:58) menjelaskan beberapa pola manajemen laba, yang dapat dilakukan oleh manajemen, yaitu: (1) "Taking a bath." Cara ini dilakukan dalam periode di mana terjadi organizational stress atau reorganisasi, termasuk pengangkatan CEO baru. Jika perusahaan harus melaporkan rugi maka manajer terdorong untuk melaporkan rugi yang sekalian besar dengan cara melakukan penghapusan aktiva atau pembuatan cadangan untuk biaya masa mendatang. Cara ini meningkatkan kemungkinan melaporkan laba yang lebih tinggi, dan memperoleh bonus, di masa mendatang, (2) Minimalisasi laba. Cara ini serupa namun tidak seekstrem taking a bath. Biasanya dilakukan dalam kondisi laba tinggi oleh perusahaan yang memiliki visibilitas politis yang tinggi (3) Maksimalisasi laba. Manajer melakukan hal ini dengan tujuan mengejar bonus, dan akan dilakukan sepanjang tidak menyebabkan laba laporan lebih tinggi daripada batas atas skema bonus. Perusahaan yang mendekati batas pelanggaran debt covenant juga cenderung memaksimalkan laba (4) Perataan laba. Pola ini mungkin merupakan pola manajemen laba yang paling menarik. Dari penelitian Healy terlihat bahwa manajer memiliki insentif untuk meratakan laba agar tetap berada di antara batas bawah (bogey) dan batas atas (cap) skema bonus. Di samping itu, manajer yang risk-averse lebih menyukai laba yang tidak terlalu berfluktuasi sehingga juga cenderung melakukan perataan laba. Motivasi lain yang dapat menyebabkan manajer melakukan perataan laba adalah keinginan untuk meratakan rasio-rasio debt covenant, mengurangi kemungkinan dipecat, dan mengkomunikasikan informasi mengenai prospek perusahaan kepada investor.

\subsection{Hubungan antar Variabel}

\section{a. Pengaruh Struktur Kepemilikan terhadap Manajemen Laba}

Struktur kepemilikan dan manajemen laba merupakan kondisi yang saling terkait. Struktur kepemilikan merupakan proporsi kepemilikan dalam perusahaan yang menunjukkan antara kepemilikan institusi dan kepemilikan keluarga. Jensen dan Meckling (1976), Iturriaga dan Sanz (2001) menyatakan kepemilikan institusi dan kepemilikan keluarga merupakan dua mekanisme utama tata kelola perusahaan yang dapat membantu mengurangi konflik keagenan. Penelitian mengenai struktur kepemilikan menjadikan kepemilikan institusional menjadi perhatian dalam penelitian ini.

Siregar dan Utama (2008) dan Jones et al. (2009) menterjemahkan kepemilikan institusional sebagai kepemilikan oleh institusi keuangan diantaranya kepemilikan oleh perusahaan asuransi, perbankan termasuk bank investasi, perusahaan dana pensiun, dan mutual fund. Kepemilikan institusional umumnya dapat bertindak sebagai pihak yang memonitor perusahaan. Perusahaan dengan kepemilikan institusional yang besar mengindikasikan kemampuannya untuk memonitor pihak manajemen. Fungsi pemonitoran menjadi penting ketika 
kepemilikan institusional menjadi dasar dalam menilai tindakan manajemen laba. Shleifer dan Vishny (1986) mengungkapkan bahwa tingkat kepemilikan institusional yang besar akan mempengaruhi nilai pasar perusahaan. Semakin besar kepemilikan institusional maka semakin efisien pemanfaatan aktiva perusahaan dan dapat diharapkan juga dapat bertindak sebagai pencegahan terhadap pemborosan yang dilakukan oleh manajemen. Selain itu semakin tinggi tinggi kepemilikan institusional juga diharapkan semakin kuat pengendalian internal terhadap perusahaan di mana dapat mengurangi agency cost $\mathrm{di}$ perusahaan. Kepemilikan institusional di dalam perusahaan akan mendorong manajemen melaporkan laba perusahaan sesuai dengan target dan memiliki kemampuan yang lebih besar untuk menganalisa akibat dari tindakan manajemen saat ini dan di masa yang akan datang (Moh'd, 1998).

Beberapa penelitian menguji pengaruh struktur kepemilikan terhadap manajemen laba. Penelitian Siregar dan Utama (2008) menggunakan pengaruh struktur kepemilikan terhadap manajemen laba. Peneliti menggunakan perusahaan manufaktur terdaftar di Bursa Efek Indonesia sebagai sampel penelitian. Hasil penelitiannya menunjukkan kepemilikan institusional berhubungan negatif terhadap manajemen laba akrual.

Wang (2009) menguji pengaruh struktur kepemilikan terhadap manajemen laba dengan

menggunakan perusahaan publik dan privat di Amerika Serikat. Peneliti menggunakan perusahaan publik dan privat di Amerika Serikat selama kurun waktu 1992-2002. Hasil penelitian menunjukkan bahwa struktur kepemilikan institusional pada perusahaan publik sulit disederhanakan namun dengan banyaknya pihak pengawasan yang terlibat di dalamnya motivasi melakukan manajemen laba menjadi rendah jika dibandingkan dengan perusahaan swasta.

Namun penelitian Chin et al. (2009) yang menguji pengaruh struktur kepemilikan terhadap manajemen laba di negara Taiwan tidak sesuai dengan penelitian Siregar dan Utama (2008). Hasil penelitiannya menemukan bahwa internasionalisasi perusahaan yang lebih tinggi berhubungan positif dengan manajemen laba. Hal ini menunjukkan bahwa semakin tinggi kepemilikan institusional dalam perusahaan, maka manajemen laba menjadi semakin meningkat. Hal ini terjadi karena Chin et al. (2009) menggunakan lingkup negara yaitu jumlah negara asing di mana perusahaan berinvestasi di Negara Taiwan yang cenderung memiliki nilai kepemilikan institusional yang rendah.

Penelitian yang menggunakan variabel struktur kepemilikan dan manajemen laba dintaranya Siregar dan Utama (2008), Wang (2009) dan Chin et al. (2009) telah mengungkapkan adanya pengaruh dari struktur kepemilikan dalam perusahaan, baik kepemilikan institusi maupun kepemilikan keluarga. Secara keseluruhan, penelitian tersebut mengungkapkan hasil yang menunjukkan hubungan struktur kepemilikan institusional dengan manajemen laba. Tindakan manajemen laba akrual perusahaan seharusnya dapat dikendalikan dengan kepemilikan institusional yang tinggi. Hal ini terjadi karena struktur kepemilikan 
institusional mampu memonitor pihak manajemen dalam melakukan manajemen laba. Berdasarkan beberapa penelitian tersebut maka dapat diketahui bahwa proporsi kepemilikan institusional akan mempengaruhi secara negatif manajemen laba pada perusahaan.

\section{b. Pengaruh ukuran perusahaan terhadap Manajemen Laba}

Ukuran perusahaan merupakan skala perusahaan yang dapat diklasifikasikan ke dalam besar kecilnya suatu perusahaan di dalam industri sejenis. Untuk mengetahui pengklasifikasian ukuran perusahaan perlu dilakukan pemisahan antar perusahaan. Terdapat berbagai cara dalam mengklasifikasikan perusahaan berdasarkan ukuran, antara lain: total aset, log size, nilai pasar saham, dan lainnya (Lee dan Choi, 2002).

Lee dan Choi (2002) menguji hubungan antara ukuran perusahaan dan manajemen laba. Penelitian tersebut menggunakan ukuran perusahaan dengan membagi perusahaan ke dalam perusahaan besar dan kecil. Hasil penelitian menunjukkan ukuran perusahaan merupakan variabel yang mempengaruhi tendensi perusahaan untuk melakukan manajemen laba. Hal ini terjadi karena semakin besar ukuran perusahaan maka akan cenderung disorot dalam segala kegiatannya sehingga peluang untuk melakukan manajemen laba menjadi lebih kecil.

Siregar dan Utama (2008) mengungkapkan secara umum ukuran perusahaan terbagi menjadi perusahaan besar (large size), perusahaan menengah (medium size) dan perusahaan kecil (small size). Penelitiannya juga menguji pengaruh ukuran perusahaan terhadap manajemen laba. Hasil penelitian menunjukkan ukuran perusahaan secara konsisten mempunyai pengaruh negatif signifikan terhadap besarnya manajemen laba yang dilakukan perusahaan terdaftar di Bursa Efek Indonesia. Hal ini menunjukkan semakin besar ukuran perusahaan maka semakin kecil manajemen laba yang dilakukan perusahaan.

Penelitian yang menggunakan variabel ukuran perusahaan dan manajemen laba dintaranya Lee dan Choi (2002) dan Siregar dan Utama (2008) telah mengungkapkan adanya pengaruh dari ukuran perusahaan terhadap manajemen laba. Hal ini diketahui dari ukuran perusahaan yang semakin besar dan manajemen laba yang dilakukan. Total aset dapat menggambarkan besar kecilnya ukuran perusahaan. Perusahaan besar memiliki kompleksitas organisasi yang lebih tinggi dibandingkan dengan perusahaan kecil, sehingga hal ini akan membuat perusahaan besar cenderung disorot dalam segala kegiatan bisnisnya oleh stakeholder sehingga peluang untuk melakukan manajemen laba menjadi lebih kecil. Perusahaan besar juga menjaga agar reputasi nama baik dan kinerja yang dibangun selama ini tidak rusak hanya karena tindakan manajemen laba tersebut. Penelitian ini menggunakan ukuran perusahaan sebagai variabel yang diuji karena peneliti ingin menguji pengaruh ukuran perusahaan yang merupakan salah satu dari motivasi politik dalam manajemen laba (Watt dan Zimmerman,1986). Berdasarkan beberapa penelitian tersebut maka dapat 
diketahui bahwa ukuran perusahaan akan mempengaruhi secara negatif manajemen laba pada perusahaan.

\section{c. Pengaruh dividen terhadap Manajemen Laba}

Dewenter et al. (2000) menguji perbedaan konflik antara manajemen dan pemegang saham atas kebijakan dividen di Jepang dan Amerika Serikat. Permasalahan yang diteliti adalah tingkat asimetri informasi mengenai kandungan informasi pengumuman dividen dan konflik keagenan. Temuan penelitian ini adalah konflik keagenan di Jepang lebih rendah dibandingkan dengan di Amerika Serikat. Hasil penelitian ini menyimpulkan bahwa masalah keagenan berpengaruh terhadap kebijakan dividen.

Achmad (2007) mencoba kembali membuktikan kebenaran motivasi manajemen melakukan tindakan manajemen laba yang dituangkan dalam 3 (tiga) hipotesis dari positive accounting theory, yaitu the bonus plan hypothesis, debt covenant hypothesis, dan the political cost hypothesis (size hypothesis). Watt dan Zimmerman (1986: 257--262) dengan seting perusahaan yang ada di Indonesia. Data yang dianalisis adalah laporan keuangan periode 2003-- 2005 dengan ordinary least square regression analysis.

Setelah dianalisis secara statistik penelitian dilanjutkan dengan melakukan investigasi langsung ke perusahaan yang discretionary accrualls-nya ekstrim. Hasil temuan memberikan dukungan pada hipotesis utang dan politikal proses. Rencana bonus tidak berpengaruh pada manajemen laba. Achmad (2007) menyatakan bahwa motivasi rencana bonus, perjanjian utang, dan biaya politik merupakan motivasi manajemen laba yang berlaku umum (bernilai global) dalam praktik-praktik bisnis pengelolaan perusahaan. Hasil investigasi terhadap perusahaan yang dijadikan sampel dalam investigasi menemukan beberapa alasan manajer melakukan tindakan manajemen laba antara lain. (1) pembayaran pajak, (2) penggeseran kinerja (sebagai akibat biaya politik), (3) laba dari restrukturisasi utang, (4) kesinambungan usaha, (5) motivasi rencana bonus, (6) pembayaran dividen, dan (7) debt covenant.

Hasil temuan Achmad (2007) masih memiliki kelemahan. Pertama, sampel perusahaan tidak dikontrol antara perusahaan yang terindikasi melakukan manajemen laba secara ekstrem dengan perusahaan yang tidak mengelola laba. Kedua, penelitian menggunakan sampel hanya 83 perusahaan sehingga model prediksi discretonary accruals yang dihasilkan relatif masih lemah. Ketiga, investigasi praktik manajemen laba menghasilkan motivasi dan strategi yang bersifat indikasi dan bukan pembuktian yang dapat dijadikan dasar dalam penilaian kewajaran suatu transaksi secara ekonomi dan hukum.

Penelitian yang menganalisis hubungan kebijakan dividen dengan manajemen laba seperti yang dilakukan oleh Savov (2006). Tujuan penelitiannya adalah mengembangkan analisis pada manajemen laba untuk menguji hubungan interaksi antara perilaku pelaporan perusahaan, kebijakan dividen dan investasi, dan kesalahan penentuan harga saham (stock market mispricing) dan dua varibel 
tambahan, yaitu nilai pasar (market to book ratio) dan utang (debt). Penelitian dilakukan di perusahaan-perusahaan Jerman dengan menggunakan data laporan keuangan periode 1982-2003 dan menggunakan analisis regresi. Manajemen laba diproksi menggunakan dicretionary accrual dengan metode pengukuran yang diadopsi dari model modifikasian Jones (1991). Kebijakan dividen diukur dengan perubahan dividen yang berdasarkan Litner (1956) model.

Hasil penelitian menemukan bahwa investasi berhubungan positif dengan manajemen laba dan kebijakan dividen berhubungan secara negatif terhadap manajemen laba. Hasil temuan Savov (2006) menunjukkan bahwa kebijakan dividen berhubungan negatif terhadap manajemen laba. Artinya semakin tinggi dividen yang dibayarkan maka manajemen semakin menurunkan laba dengan cara melakukan manajemen laba dengan pola income decreasing.

\section{METODE PENELITIAN}

Penelitian dilakukan di Bursa Efek Indonesia Jl. Sudirman Kav. 52-53 Jakarta, 12190 Indonesia Telp. 021-5150515 atau melalui websitenya www.idx.co.id.

Tabel 1. Kriteria Sampel

\begin{tabular}{lll} 
No. & Kriteria Sampel & Jumlah \\
\hline & $\begin{array}{l}\text { Perusahaan manufaktur yang } \\
\text { terdaftar di BEI }\end{array}$ & 141 \\
1. & $\begin{array}{l}\text { Perusahaan yang listing di BEI } \\
\text { setelah tahun 2010 }\end{array}$ & 22 \\
& $\begin{array}{l}\text { Perusahaan yang tidak } \\
\text { mengeluarkan dividen secara } \\
\text { kontinue periode 2010-2014 }\end{array}$ & \\
& Jumlah Sampel & $\mathbf{1 8}$ \\
& Periode penelitian (5 tahun) & $\mathbf{9 0}$
\end{tabular}

Sumber: Bursa Efek Indonesia

Berdasarkan kriteria tersebut, penulis menetapkan sebanyak 18 sampel perusahaan manufaktur yang terdaftar di Bursa Efek Indonesia periode 20102014. 
Menurut Sugiyono (2012:115), populasi adalah wilayah generalisasi yang terdiri atas: objek/subjek yang mempunyai kualitas dan karakteristik tertentu yang ditetapkan oleh peneliti untuk dipelajari dan kemudian ditarik kesimpulannya. Populasi dalam penelitian ini adalah perusahaan manufaktur yang terdaftar di Bursa Efek Indonesia 2010-2014. Daftar perusahaan manufaktur yang terdaftar saat ini berjumlah 141 perusahaan. Pengukuran sampel merupakan langkah untuk menentukan besarnya sampel yang akan diambil dalam melaksanakan penelitian dalam suat obyek.

Untuk menentukan besarnya sampel bisa dilakukan dengan perhitungan statistik atau berdasarkan estimasi penelitian. Pengambilan sampel ini harus dilakukan sedemikian rupa sehingga diperoleh sampel yang benar-benar dapat berfungsi atau dapat menggambarkan keadaan populasi yang sebenarnya. Dengan istilah lain, sampel harus representatif

\section{HASIL- HASIL PENELITIAN}

\section{Hasil Uji Asumsi Klasik}

Sesuai dengan tujuan penelitian yang akan dilaksanakan, yaitu untuk mengetahui bagaimana pengaruh struktur kepemilikan, ukuran perusahaan dan dividen terhadap manajemen laba pada perusahaan manufaktur yang terdaftar di Bursa Efek Indonesia secara parsial maupun secara simultan, maka penulis menetapkan alat statistik berupa teknik analisis regresi berganda untuk membantu melakukan proses perhitunganya. Dalam analisis regresi berganda dikemukakan asumsi-asumsi yang harus dipenuhi agar penaksiran parameter dan koefisienkoefisien regresi tidak bias dan mendekati keadaan yang sesungguhnya. Sehubungan dengan itu, sebelum dilakukan analisis data dan pengujian hipotesis terlebih dahulu akan dilakukan pengujian terhadap asumsi-asumsi dalam analisis regresi sebagai berikut:

\section{Uji Normalitas}

Pengujian terhadap normalitas regresi penelitian ini digunakan P-P plot dari regresi residual yang distandarisasi untuk menguji normalitas. Asumsi ini menyatakan bahwa residual-residual berdistribusi normal atau kesalahan pengganggu mengikuti distribusi normal. Jika banyak nilai yang diplot secara kasar disepanjang garis normal (diagonal), maka hal ini menunjukkan asumsi normalitas dipenuhi.

Hasil P-P plot regresi disajikan pada Grafik P-P plot terlihat bahwa semua nilai diplot di sekitar garis diagonal dan arahnya juga searah dengan diagonal. Jadi asumsi normalitas dipenuhi yang disajikan dalam gambar sebagai berikut: 


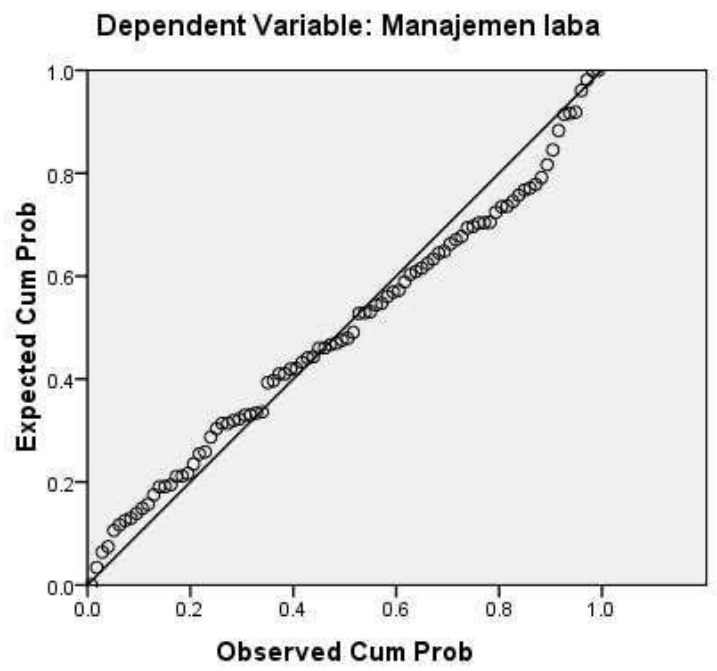

Gambar 1.

P-P plot Uji Normalitas Regr

data > 0.05, maka data berdistribusi normal. Hasil uji normalitas data disajikan dalam Tabel 2. sebagai berikut :

Tabel 2.

\section{Hasil Uji Normalitas}

One-Sample Kolmogorov-Smirnov Test

Unstandardized

Residual

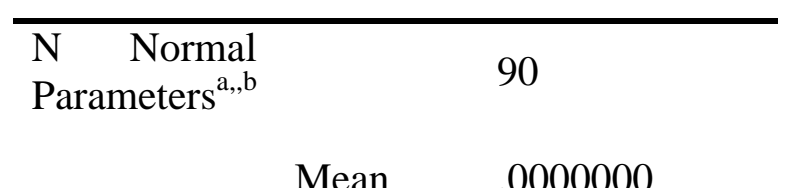

$\begin{array}{ll}\text { Std. } & 00205206\end{array}$

Most

Extreme Absolute $\quad .096$

Differences

$$
\begin{array}{ll}
\text { Positive } & .096 \\
\text { Negative } & -.058
\end{array}
$$

Kolmogorov-Smirnov Z $\quad .907$

Asymp. Sig. (2-tailed) $\quad .383$ 

a. Test distribution is Normal
b. Calculated from data.
Sumber : Output SPSS (data diolah)

Dari uji statistik Kolmogrov-Smirnov di atas, menunjukkan bahwa seluruh residual variabel terdistribusi secara normal. Hal ini terlihat dari probabilitas signifikansinya yaitu 0,383 sehingga probabilitas signifikansi jauh di atas $\alpha=$ 0,05, Hal ini berarti data variabel terdistribusi secara normal.

Pengujian normalitas data juga dapat dilakukan dengan one sample Kolmogorov- smirnov test. Tujuan uji ini untuk menentukan metode statistik yang akan digunakan dalam analisa. Jika data berdistribusi normal, maka analisa selanjutnya dapat menggunakan metode statistic parametric, sedangkan jika data tidak berdistribusi normal, maka metode statistic parametric tidak dapat digunakan dalam analisa, jadi harus menggunakan metode statistic nonparametrik. Adapun kriteria pengujian pada taraf nyata 0.05 adalah : Jika probabilitas signifikansi b. Uji Multikoliniearitas Pedoman suatu model regresi yang bebas multikolinearitas korelasi antara variabel bebas (independent) secara tidak sempurna atau tidak secara kuat berhubungan satu sama lain. Ukuran besarnya korelasi yang bebas multikolinearitas dapat diukur melalui nilai tolerance (Variance Inflation Factor) dari masing- masing variabel dalam program komputer SPSS Ver. 20.0 yaitu jika nilai toleransi $<0,1$ atau VIF $>10$ maka hal mengindikasikan terdapatnya multikolinearitas. Berikut di bawah ini hasil pengolahan data yang dapat menjelaskan apakah antar variabel independen multikolinearitas.

\section{Tabel 3.}

\section{Hasil Uji Multikolinearitas Data}

\section{Coefficients $^{\mathbf{a}}$}

Collinearity Statistics

Model Tolerance VIF

\begin{tabular}{|c|c|c|c|}
\hline 1 & Struktur kepemilika & .718 & 1.392 \\
\hline 2 & Ukuran perusahaan & .718 & 1.392 \\
\hline & Dividen & .897 & \\
\hline
\end{tabular}


a. Dependent Variable: Manajemen laba

Sumber: Lampiran Output SPSS (2016)

Dari tabel 3., dapat dilihat bahwa nilai toleransi dari setiap variabel bebas menunjukkan angka $>0,10$ dan semuanya memiliki nilai VIF lebih kecil dari 10, sehingga dapat disimpulkan bahwa pada model regresi tidak terdapat problem multikolinearitas dalam model regresi.

\section{Uji Heteroskedastisitas}

Asumsi ini menyatakan bahwa variansi residual di sekitar garis regresi adalah konstan untuk setiap kombinasi dari nilai variabel independennya. Jika dalam regresi grafik scatterplots of residuals tidak membentuk pola tertentu (bergelombang, melebar kemudian menyempit, pola linear atau kuadratis), maka dalam regresi asumsi heteroskedastisitas tidak terjadi. Dapat pada Grafik scatterplot, titik-titik menyebar tidak membentuk pola tertentu, maka asumsi tidak terjadi heteroskedastisitas dipenuhi, disajikan dalam gambar sebagai berikut :

\section{Gambar 2 Scatterplot Uji Heteroskedastisitas Regresi}

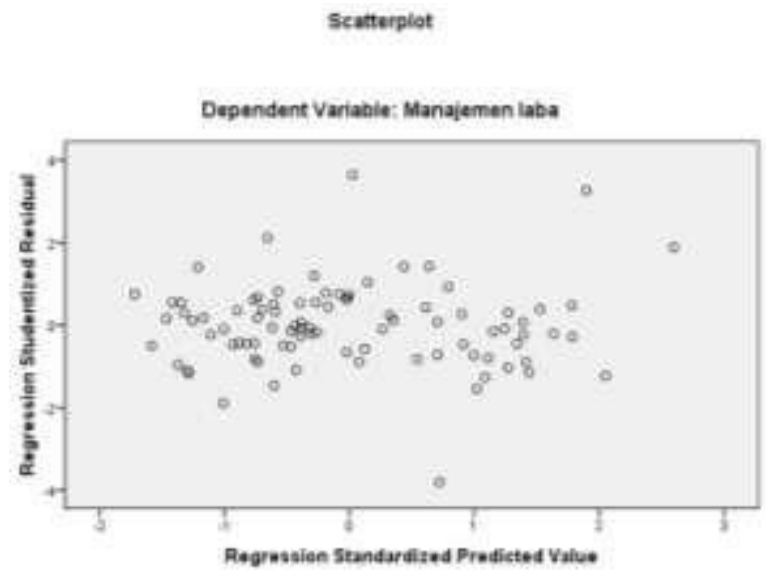

Sumber: Lampiran Output SPSS (2016)

\section{Uji Autokorelasi}

Autokorelasi muncul karena observasi yang berurutan sepanjang waktu berkaitan satu sama lain, masalah ini timbul karena residual (kesalahan pengganggu) tidak bebas dari satu observasi ke observasi lainnya. Otokorelasi dari residual biasanya terjadi bila analisis regresi memuat data time series. Hasil uji autokorelasi disajikan dalam Tabel 4. sebagai berikut :

\section{Tabel 4.}

\section{Hasil Uji Autokorelasi}

Model Summary 
Adjusted R Std. Error of the Durbin-

\begin{tabular}{llllll} 
Model & R & \multicolumn{2}{l}{ R Square Square } & Estimate & Watson \\
\hline 1 & $.420^{\mathrm{a}}$ & .176 & .147 & 7 & 2,08754780965 \\
& & &
\end{tabular}

299E-3

a. Predictors: (Constant), Dividen, Struktur kepemilikan, Ukuran perusahaan

b. Dependent Variable: Manajemen laba

Sumber: Lampiran Output SPSS (2016)

Pada tabel 4. di atas, hasil Durbin-Watson statistik (DW stat) yaitu sebesar 2,093. Selanjutnya dibandingkan nilai DW stat dengan DW tabel yang terdiri dari dua nilai yaitu batas bawah (dL) dan batas atas (dU). Dengan $\mathrm{k}=3$ karena jumlah variabel bebas yang digunakan sebanyak 3 dan $\mathrm{n}=90$, maka didapatkan pada table Durbin Watson $(\alpha=5 \%)$ batas dL yaitu 1,5889 dan dU yaitu 1,7264 . Maka dapat dinyatakan bahwa hasil dari uji statistic Durbin-Watson berada pada daerah $\mathrm{dU} \leq \mathrm{d} \leq 4-\mathrm{dU}$ atau $1,7264 \leq 2,093 \leq 2,2736$ sehingga dapat diputuskan bahwa tidak terdapat autokorelasi.

\section{Analisis Regresi Linier berganda}

Untuk mengetahui bagaimana pengaruh struktur kepemilikan, ukuran perusahaan dan dividen terhadap manajemen laba pada perusahaan manufaktur yang terdaftar di Bursa Efek Indonesia maka penulis menggunakan teknik analisis regresi dengan bantuan program computer SPSS Versi 20.0. Hasil pengolahan data analisis regresi tersebut sebagai berikut :

Tabel 5.

Hasil Uji Regresi Linier Berganda

Coefficients $^{\mathrm{a}}$ 


\author{
Unstandardiz Standardi \\ ed zed \\ Coefficie \\ Coefficients nts
}

Model B Error Beta $\mathrm{t}$ Sig.

\begin{tabular}{llllll}
\hline $\begin{array}{l}\text { (Constant } \\
1 \quad\end{array}$ & .019 & .005 & & 3.852 .000 \\
$\begin{array}{l}\text { Struktur } \\
\text { kepemilikan }\end{array}$ & -.002 & .002 & -.157 & 1.361 .177 \\
$\begin{array}{l}\text { Ukuran } \\
\text { perusahaan }\end{array}$ & -.001 & .000 & -.448 & 3.877 .000 \\
Dividen & .002 & .001 & .265 & 2.560 & .012
\end{tabular}

Berdasarkan hasil analisis regresi di atas, maka dapat diperoleh suatu persamaan garis regresi sebagai berikut :

$\hat{Y}=0,019-0,002 X_{1}-0,001 X_{2}+0,002 X_{3}$

Persamaan diatas dapat diinterpretasikan sebagai berikut :

1. Konstanta a sebesar 0,019 menyatakan bahwa jika variabel $X_{1}, X_{2}$, dan $X_{3}$ konstan, maka variabel Y adalah 0,019 .

2. Koefisien regresi $X_{1}$ sebesar $-0,002$ menyatakan bahwa setiap penambahan variabel $\mathrm{X}_{1}$ (struktur kepemilikan) sebesar satu satuan akan menurunkan variabel Y (manajemen laba) sebesar 0,002 dengan asumsi variabel bebas lain besarnya konstan.

3. Koefisien regresi $X_{2}$ sebesar $-0,001$ menyatakan bahwa setiap penambahan variabel $\mathrm{X}_{2}$ (struktur kepemilikan) sebesar satu satuan akan menurunkan variabel Y (manajemen laba) sebesar 0,001 dengan asumsi variabel bebas lain besarnya konstan. 
4. Koefisien regresi $X_{3}$ sebesar 0,002 menyatakan bahwa setiap penambahan variabel $\mathrm{X}_{3}$ (dividen) sebesar satu satuan akan meningkatkan variabel $\mathrm{Y}$ (manajemen laba) sebesar 0,002 dengan asumsi variabel bebas lain besarnya konstan.

Uji Hipotesis Nilai thitung untuk variabel struktur kepemilikan $\left(\mathrm{X}_{1}\right)$ lebih besar dari nilai -ttabel, yaitu -1,361 > - 1,988. Dengan demikian Ho diterima dan Ha ditolak. Sehingga dapat disimpulkan bahwa variabel struktur kepemilikan secara parsial tidak mempunyai pengaruh yang signifikan terhadap manajemen laba pada perusahaan manufaktur yang terdaftar di Bursa Efek Indonesia.

Nilai t-hitung untuk variabel ukuran perusahaan $\left(\mathrm{X}_{2}\right)$ lebih kecil dari nilai ttabel, yaitu $-3,877 \leq-1,988$. Dengan demikian Ho ditolak dan Ha diterima. Sehingga dapat disimpulkan bahwa variabel ukuran perusahaan secara parsial mempunyai pengaruh signifikan terhadap manajemen laba pada perusahaan manufaktur yang terdaftar di Bursa Efek Indonesia.

Nilai thitung untuk variabel dividen $\left(\mathrm{X}_{3}\right)$ lebih besar dari nilai t-tabel, yaitu Dengan demikian Ho ditolak dan Ha diterima. Sehingga dapat disimpulkan bahwa variabel dividen secara parsial mempunyai pengaruh yang signifikan manajemen laba pada manufaktur yang terdaftar Indonesia.

Hasil analisis regresi yang menunjukkan nilai F-hitung $=6,131$ sedangkan nilai $F$ tabel pada $\alpha=0,05$ dan derajat bebas 3 dan $\mathrm{n}=90 \mathrm{df}=86$ adalah 6,131 Jadi F-hitung $=6,131>\mathrm{F}$ tabel 2,71. Ini berarti bahwa H0 ditolak dan Ha diterima signifikansi $\alpha=0,05$.

Dengan demikian dapat disimpulkan bahwa variabel dan X3 secara simultan berarti untuk model regresi di atas atau dengan kata lain bahwa (Struktur kepemilikan, ukuran dan dividen) secara simultan signifikan terhadap manajemen laba. Uji Koefisien Determinasi Besarnya pengaruh struktur kepemilikan, ukuran perusahaan dan dividen secara simultan terhadap manajemen laba pada manufaktur yang terdaftar di Bursa Efek Indonesia ditunjukkan oleh koefisien determintasi (R2) pada tabel 6. berikut:

Tabel 6

\section{Hasil Uji Koefisien Determinasi}

Model Summary ${ }^{b}$

Std. Error of the

Model R R Square Adjusted R Square Estimate

\begin{tabular}{lllll}
\hline & & & $2,087547809657299 \mathrm{E}$ \\
1 & $.420^{\mathrm{a}}$ & .176 & .147 & -3
\end{tabular}


a. Predictors: (Constant), Dividen, Struktur kepemilikan, Ukuran perusahaan

b. Dependent Variable: Manajemen laba

Sumber: Lampiran Output SPSS (2016)

Pada tabel 6. diatas, diperoleh Koefisien determinasi ganda $\left(\mathrm{R}^{2}\right)$ menunjukkan proporsi atau persentase variasi total dalam variabel $\mathrm{Y}$ yang dapat dijelaskan oleh variabel independen $\mathrm{X}_{1}, \mathrm{X}_{2}$, dan $\mathrm{X}_{3}$ secara simultan (bersamasama). Hasil analisis koefisien determinasi yang disajikan pada tabel 4.12. menunjukkan bahwa $\mathrm{R}^{2}=0,176$, ini dapat ditafsirkan bahwa pengaruh struktur kepemilikan, ukuran perusahaan dan dividen secara simultan terhadap manajemen laba sebesar 0,176 atau dengan kata lain $17,6 \%$ variasi nilai variabel $Y$ (manajemen laba) dapat diterangkan oleh variabel struktur kepemilikan, ukuran perusahaan dan dividen, sedangkan sisanya sebesar 82,4\% merupakan kontribusi atau pengaruh variabel lainnya yang tidak dimasukkan ke dalam model penelitian ini seperti profitabilitas, nilai perusahaan, financial leverage, dewan komisaris independen dan variabel-variabel lainnya.

Variabel struktur kepemilikan secara parsial tidak mempunyai pengaruh yang signifikan terhadap manajemen laba pada perusahaan manufaktur yang terdaftar di Bursa Efek Indonesia.

Struktur kepemilikan dan manajemen laba merupakan kondisi yang saling terkait. Struktur kepemilikan merupakan proporsi kepemilikan dalam perusahaan yang menunjukkan antara kepemilikan institusi dan kepemilikan keluarga. Jensen dan Meckling (1976), Iturriaga dan Sanz (2001) menyatakan kepemilikan institusi dan kepemilikan keluarga merupakan dua mekanisme utama tata kelola perusahaan yang dapat membantu mengurangi konflik keagenan. Penelitian mengenai struktur kepemilikan menjadikan kepemilikan institusional menjadi perhatian dalam penelitian ini.

Hasil penelitian menunjukkan bahwa struktur kepemilikan tidak berpengaruh terhadap manajemen laba pada perusahaan manufaktur yang terdaftar di Bursa Efek Indonesia, sehingga hasil penelitian ini tidak mendukung teori yang menyatakan bahwa besar kecilnya kepemilikan institusional dalam perusahaan mempengaruhi perusahaan dalam melakukan tindakan manajemen laba.

\section{Interpretasi Hasil Penelitian}

Berdasarkan hasil penelitian diatas maka dapat diintepretasikan hasil sebagai berikut :

1. Pengaruh struktur kepemilikanterhadap manajemen laba pada perusahaan manufaktur yang terdaftar di Bursa Efek Indonesia Hasil penelitian 
menunjukkan bahwa struktur kepemilikan tidakberpengaruh signifikan terhadap manajemen laba. Hal ini berdasarkan hasil pengujian yang menunjukkan nilai $t_{\text {hitung }}$ untuk variabel struktur kepemilikan $\left(\mathrm{X}_{1}\right)$ lebih besar dari nilai $t_{\text {-tabel}}$, yaitu -1,361 > - 1,988. Dengan demikian Ho diterima dan Ha ditolak. Sehingga dapat disimpulkan bahwa

2. Pengaruh ukuran perusahaan terhadap manajemen laba pada perusahaan manufaktur yang terdaftar di Bursa Efek Indonesia Hasil penelitian menunjukkan bahwa ukuran perusahaan berpengaruh signifikan terhadap manajemen laba. Hal ini berdasarkan hasil pengujian yang menunjukkan nilai $t_{\text {hitung }}$ untuk variabel ukuran perusahaan $\left(\mathrm{X}_{2}\right)$ lebih kecil dari nilai ttabel, yaitu $-3,877 \leq-1,988$. Dengan demikian Ho ditolak dan Ha diterima. Sehingga dapat disimpulkan bahwa variabel ukuran perusahaan secara parsial mempunyai pengaruh yang signifikan terhadap manajemen laba pada perusahaan manufaktur yang terdaftar di Bursa Efek Indonesia.

Siregar dan Utama (2008) mengungkapkan secara umum ukuran perusahaan terbagi menjadi perusahaan besar (large size), perusahaan menengah (medium size) dan perusahaan kecil (small size). Penelitiannya juga menguji pengaruh ukuran perusahaan terhadap manajemen laba. Hasil penelitian menunjukkan ukuran perusahaan secara konsisten mempunyai pengaruh negatif signifikan terhadap besarnya manajemen laba yang dilakukan perusahaan terdaftar di Bursa Efek Indonesia. Hal ini menunjukkan semakin besar ukuran perusahaan maka semakin kecil manajemen laba yang dilakukan perusahaan.

Hasil penelitian menunjukkan bahwa ukuran perusahaan berpengaruh terhadap manajemen laba pada perusahaan manufaktur yang terdaftar di Bursa Efek Indonesia, sehingga hasil penelitian ini mendukung teori bahwa semakin besar ukuran perusahaan maka semakin kecil manajemen laba yang dilakukan perusahaan.

3. Pengaruh dividen terhadap manajemen laba pada perusahaan manufaktur yang terdaftar di Bursa Efek Indonesia

Hasil penelitian menunjukkan bahwa dividen berpengaruh signifikan terhadap manajemen laba. Hal ini berdasarkan hasil pengujian yang menunjukkan nilai $t_{h i t u n g}$ untuk variabel dividen $\left(\mathrm{X}_{3}\right)$ lebih besar dari nilai $\mathrm{t}_{\text {tabel}}$, yaitu 2,560 > 1,988. Dengan demikian Ho ditolak dan Ha diterima. Sehingga dapat disimpulkan bahwa variabel dividen secara parsial mempunyai pengaruh yang signifikan terhadap manajemen laba pada perusahaan manufaktur yang terdaftar di Bursa Efek Indonesia.

Dewenter et al. (2000) menguji perbedaan konflik antara manajemen dan pemegang saham atas kebijakan dividen di Jepang dan Amerika Serikat. Permasalahan yang diteliti adalah tingkat asimetri informasi mengenai kandungan informasi pengumuman dividen dan konflik keagenan. Temuan penelitian ini adalah konflik keagenan di Jepang lebih rendah 
dibandingkan dengan di Amerika Serikat. Hasil penelitian ini menyimpulkan bahwa masalah keagenan berpengaruh terhadap kebijakan dividen.

Achmad (2007) mencoba kembali membuktikan kebenaran motivasi manajemen melakukan tindakan manajemen laba yang dituangkan dalam 3 (tiga) hipotesis dari positive accounting theory, yaitu the bonus plan hypothesis, debt covenant hypothesis, dan the political cost hypothesis (size hypothesis). Watt dan Zimmerman (1986: 257--262) dengan seting perusahaan yang ada di Indonesia. Data yang dianalisis adalah laporan keuangan periode 2003--2005 dengan ordinary least square regression analysis. Setelah dianalisis secara statistik penelitian dilanjutkan dengan melakukan investigasi langsung ke perusahaan yang discretionary accrualls-nya ekstrim. Hasil temuan memberikan dukungan pada hipotesis utang dan politikal proses. Rencana bonus tidak berpengaruh pada manajemen laba. Achmad (2007) menyatakan bahwa motivasi rencana bonus, perjanjian utang, dan biaya politik merupakan motivasi manajemen laba yang berlaku umum (bernilai global) dalam praktik-praktik bisnis pengelolaan perusahaan. Hasil investigasi terhadap perusahaan yang dijadikan sampel dalam investigasi menemukan beberapa alasan manajer melakukan tindakan manajemen laba antara lain. (1) pembayaran pajak, (2) penggeseran kinerja (sebagai akibat biaya politik), (3) laba dari restrukturisasi utang, (4) kesinambungan usaha, (5) motivasi rencana bonus, (6) pembayaran dividen, dan (7) debt covenant.

Hasil penelitian menunjukkan bahwa dividen berpengaruh terhadap manajemen laba pada perusahaan manufaktur yang terdaftar di Bursa Efek Indonesia, sehingga hasil penelitian ini mendukung teori bahwa besar kecilnya dividen yang dikeluarkan perusahaan mempengaruhi perusahaan dalam melakukan tindakan manajemen laba.

4. Pengaruh struktur kepemilikan, ukuran perusahaan dan dividen terhadap manajemen laba pada perusahaan manufaktur yang terdaftar di Bursa Efek Indonesia

Hasil penelitian menunjukkan bahwa struktur kepemilikan, ukuran perusahaan dan dividen terhadap manajemen laba pada perusahaan manufaktur yang terdaftar di Bursa Efek Indonesia. Hal ini berdasarkan hasil pengujian yang menunjukkan nilai $F_{\text {hitung }}=6,131$ sedangkan nilai $\mathrm{F}$ tabel pada $\alpha=0,05$ dan derajat bebas 3 dan $\mathrm{n}=90 \mathrm{df}=86$ adalah 6,131 Jadi $\mathrm{F}_{\text {hitung }}=6,131>\mathrm{F}$ tabel 2,71. Ini berarti bahwa $\mathrm{H}_{0}$ ditolak dan $\mathrm{Ha}$ diterima pada tingkat signifikansi $\alpha=0,05$. Dengan demikian dapat disimpulkan bahwa variabel $\mathrm{X}_{1}, \mathrm{X}_{2}$ dan $\mathrm{X}_{3}$ secara simultan berarti untuk model regresi di atas atau dengan kata lain bahwa (Struktur kepemilikan, ukuran perusahaan dan dividen) secara simultan berpengaruh signifikan terhadap manajemen laba. 
Penelitian Siregar dan Utama (2008) menyimpulkan terdapat pengaruh struktur kepemilikan terhadap manajemen laba. Lee dan Choi (2002) menguji hubungan antara ukuran perusahaan dan manajemen laba. Penelitian tersebut menggunakan ukuran perusahaan dengan membagi perusahaan ke dalam perusahaan besar dan kecil. Hasil penelitian menunjukkan ukuran perusahaan merupakan variabel yang mempengaruhi tendensi perusahaan untuk melakukan manajemen laba. Hasil temuan Savov (2006) menunjukkan bahwa kebijakan dividen berhubungan negatif terhadap manajemen laba. Hal ini dapat menunjukkan bahwa perubahan struktur kepemilikan, ukuran perusahaan dan kebijakan dividen yang dilakukan perusahaan secara simultan akan berdampak signifikan pada kemungkinan perusahaan manajemen laba.

\section{SIMPULAN}

Hasil penelitian telah diuraikan pada bab sebelumnya, sehingga dapat disimpulkan hal-hal sebagai berikut :

1. Struktur kepemilikan tidak berpengaruh negatif dan signifikan terhadap manajemen laba pada perusahaan manufaktur yang terdaftar di Bursa Efek Indonesia, sehingga ha ${ }_{1}$ tidak terbukti. Hal ini menunjukkan bahwa tinggi rendahnya struktur kepemilikan institusional, tidak berdampak signifikan pada kemungkinan perusahaan melakukan tindakan manajemen laba.

2. Ukuran perusahaan berpengaruh negatif dan signifikan terhadap manajemen laba pada perusahaan manufaktur yang terdaftar di Bursa Efek Indonesia, sehingga ha ${ }_{2}$ terbukti. Hal ini menunjukkan bahwa semakin tinggi ukuran perusahaan, semakin kecil kemungkinan perusahaan melakukan tindakan manajemen laba.

3. Dividen berpengaruh positif dan signifikan terhadap manajemen laba pada perusahaan manufaktur yang terdaftar di Bursa Efek Indonesia, sehingga $\mathrm{ha}_{3}$ terbukti. Hal ini menunjukkan bahwa semakin tinggi dividen yang dikeluarkan perusahaan, semakin tinggi kemungkinan perusahaan melakukan tindakan laba.

4. Struktur kepemilikan, ukuran perusahaan dan dividen berpengaruh signifikan terhadap manajemen laba pada perusahaan manufaktur yang terdaftar di Bursa Efek Indonesia, sehingga ha ${ }_{4}$ terbukti. Hal ini menunjukkan bahwa peningkatan dan penurunan struktur kepemilikan, ukuran perusahaan dan dividen perusahaan akan berdampak signifikan pada kemungkinan perusahaan melakukan tindakan manajemen laba. 


\section{DAFTAR PUSTAKA}

Aurangzeb dan Tasfoura Dilawer. 2012. Earning Management and Dividend Policy: Evidence from Pakistani Textile Industry. International Journal of Academic Research in Business and Social Sciences October 2012, Vol. 2, No. 10 ISSN: 2222-6990.

Chae Chang Im, Jeong Ho Kim, dan Min Kyung Choi. 2015. Dividen Policy and Earnings Management: Based on Discretionary Accruals and Real Earnings Management. Jurnal Advanced Science and Technology Letters Vol.114 (Business 2015), pp.33-39 ISSN: 2287-1233 ASTL.

Fahmi, Irham. 2012. Analisis Laporan Keuangan. Cetakan Ke-2. Bandung: Alfabeta. Ghozali, Imam. 2011. Aplikasi Analisis Multivariate Dengan Program IBM SPSS 19. Edisi kelima. Semarang: Universitas Diponegoro

I Dewa Gede Pingga Mahariana dan I Wayan Ramantha. 2014. Pengaruh Kepemilikan Manajerial dan Kepemilikan Institusional pada Manajemen Laba Perusahaan Manufaktur di Bursa Efek Indonesia. E-Jurnal Akuntansi Universitas Udayana 7.2 (2014): 519-528 ISSN: 2302-8556.

I Gusti Ayu Made Asri Dwija Putri. 2012. Pengaruh Kebijakan Dividen dan Good Corporate Governance terhadap Manajemen Laba. Buletin Studi Ekonomi Volume 17, No. 2, Agustus 2012 ISSN 1410-4628.

Jaryanto. 2008. Manajemen Laba: Mengapa Banyak Mengundang Kontroversi?. Fokus Ekonomi. Vol.3 No.1Juni2008 :24 - 34. ISSN :1907- 6304.

Kadir, Abdul. 2010. Analisis Faktor-Faktor Yang Mempengaruhi Kebijakan Dividen Pada Perusahan Credit Agencies Go Publik Di Bursa Efek Indonesia. Jurnal Manajemen dan Akuntansi Volume 11 No 1.

Muchmuddah., Zaki. 2015. Corporate Governance Mechanism, Manajemen Laba dan Kinerja. Vol. 3 No. 1, Januari-Juni 2015 ISSN: 2476-8820.

Nabela, Yoandhika. 2012. Pengaruh Kepemilikan Institusional, Kebijakan Dividen dan Profitabilitas Terhadap Kebijakan Hutang pada Perusahaan Properti dan Real Estate di Bursa Efek Indonesia, Jurnal Manajemen, Universitas Negeri Padang, Volume 01, Nomor 01, September 2012.

Nuraina, Elva. 2012. Pengaruh Kepemilikan Institusional dan Ukuran Perusahaan terhadap Kebijakan Hutang dan Nilai Perusahaan. Jurnal Bisnis dan Ekonomi (JBE), September 2012, Hal 110-125.

Nurshadrina Kartika Sari dan Diana Dwi Astuti. 2015. Faktor yang mempengaruhi manajemen laba pada sektor perbankan Indonesia. Journal of Business and Banking Volume 5 Number 1 May - October 2015 pp. 95 - 112 ISSN 2088- 7841. 
Reviani, Dinni dan Djoko Sudantoko. 2012. Pengaruh struktur Kepemilikan, Ukuran Perusahaan dan Good Corporate Governance terhadap Manajemen Laba. Jurnal Prestasi Vol. 9 No. 1 - Juni 2012 ISSN 1411 1497.

Riyanto, Bambang. 2008. Dasar-dasar Pembelanjaan Perusahaan. Yogyakarta: Penerbit GPFE.

Sartono A,. 2010. Manajemen Keuangan Teori dan Aplikasi. (4th ed.). Yogyakarta: BPFE Sugiyono. 2012. Metode Penelitian Bisnis. Bandung : Alfabeta.

Sudana, I Made. 2011. Manajemen Keuangan Perusahaan. Erlangga, Jakarta.

Sufitrayati. 2015. Pengaruh Konsentrasi Kepemilikan Institusional, Ukuran Perusahaan dan Komposisi Dewan Komisaris terhadap Manajemen Laba. Jurnal Ekonomi Manajemen dan Akuntansi Vol.1 No.1 Th 2015: 36-44 ISSN 2460-5891.

Sugiarto. 2009. Struktul Modal, Struktur Kepemilikan Perusahaan, Permasalahan Keagenan \& Informasi Asimetri. Yogyakarta: Graha Ilmu.

Taofiqkurochman, Cecep dan Konadi, Win. 2012. Analisis Kebijakan Dividen terhadap Harga Saham pada Sektor Industri Konsumsi Periode 20002010. Jurnal Kebangsaan, Volume 1 No.2 Juli 2012

Usman Ali, Muhammad Afzal Noor, Muhammad Kashif Khurshid dan Akhtar Mahmood. 2015. Impact of Firm Size on Earnings Management: A Study of Textile Sector of Pakistan. European Journal of Business and Management ISSN 2222-1905 (Paper) ISSN 2222-2839 (Online) Vol.7, No.28, 2015. 
